\title{
Chemokine (C-C Motif) Ligand 18 Measurement
}

National Cancer Institute

\section{Source}

National Cancer Institute. Chemokine (C-C Motif) Ligand 18 Measurement. NCI

Thesaurus. Code C112237.

The determination of the amount of chemokine (C-C Motif) ligand 18 present in a sample. 